\title{
Direct Diploidization and Occurrence of Polyploidy in Saccharomycodes ludwigii
}

\author{
By TOYOHIKO YAMAZAKI \\ Department of Fermentation Technology, Yamanashi University, \\ Takeda, Kofu-shi, Yamanashi 400, Japan \\ AND YASUJI OSHIMA \\ Department of Fermentation Technology, Osaka University, \\ Yamadakami, Suita-shi, Osaka 565, Japan
}

(Received 6 September 1978)

\begin{abstract}
In a haploid cell culture of Saccharomycodes ludwigii, sporogenous diploid cells homozygous for all the genetic markers including mating type were effectively discriminated on a dye plate consisting of $15 \mu \mathrm{g}$ trypan blue and $10 \mu \mathrm{g}$ phloxine $\mathrm{B} \mathrm{ml}^{-1}$ in synthetic nutrient medium. The diploid cells appeared at a frequency of about $5 \times 10^{-3}$ that of the haploid cells and those tested bore the same alleles as the original haploid cells. The low frequency of prototrophic colonies (approximately $1 \times 10^{-8}$ ) in a mass mating culture of two different haploid strains of identical mating type and complementary auxotrophic traits, and the morphological changes observed during the suspected diploidizing process suggest that the homozygous diploids originate by direct diploidization in haploid cells. From the diploid cells homozygous for mating type, triploid and tetraploid cells were easily constructed. As with diploid cells, tetrad data from these polyploid clones suggested the absence of crossing-over at meiosis.
\end{abstract}

\section{INTRODUCTION}

Peculiar behaviour in the meiotic life cycle in Saccharomycodes ludwigii has been reported by Winge \& Laustsen (1939). In the natural habitat, vegetative cells are diploid and reduction division can occur directly in a cell. Each ascus contains four spores, one pair at each end of the ascus. Normally, each pair of spores copulates just as the spores germinate and produces a diploid cell. Hence, haploid cells are rarely produced in the natural habitat. However, it is possible to isolate haploid vegetative cells by single-spore isolation with the aid of a micromanipulator (Winge \& Laustsen, 1939; Ohara et al., 1968). Previously, we have presented genetic data suggesting the absence of meiotic crossing-over during the life cycle in Sd. ludwigii (Yamazaki et al., 1976). We have also obtained evidence suggesting polyploidy in this yeast (Yamazaki et al., 1970, 1971). The evidence, however, was not conclusive, because we employed the wild-type strains and could not investigate the nuclear behaviour in the meiotic life cycle.

This communication reports investigations on the detection and mechanism of formation of diploid cells in a haploid culture. Diploid clones were effectively isolated using a dye-plate method. The diploid cells were homozygous for all the markers tested including the matingtype alleles ( $a$ or $\alpha$ ) and showed significant ability to sporulate. The findings suggested that the diploid cells appeared by direct diploidization during the vegetative multiplication of haploid cells and not by cell fusion. Polyploid cells were easily constructed from these diploid cells. 


\section{METHODS}

Organisms. The four haploid strains, RY45-32B ( $\alpha$ arg1 met1), RY45-32C (a arg1 met1), Y27-4A (a gual) and Y27-4B ( $\alpha$ his2), and the diploid strain, RY45 (a/ $\alpha$ arg1 met1/arg1 met1), were obtained previously (Yamazaki et al., 1976). Strains RY45-32B and RY45-32C were derived from sister spores of the same ascus from strain RY45. Strains Y27-4A and Y27-4B are sister clones derived from diploid strain Y27 (a gual HIS2 + / $\alpha$ GUA1 + his2). The gua1, his2 and mating-type ( $a$ or $\alpha$ ) genes belong to the same linkage group (Yamazaki et al., 1976) (linkage group I) along with another gene, canl [a recessive resistant mutation to canavanine (100 $\mathrm{mg} \mathrm{1}^{-1}$ in nutrient medium); unpublished results]. The $\operatorname{argl}$ and $m e t 1$ genes are located on linkage group II with two more genes, ilv1 and $C Y H 1$ [a semi-dominant resistant mutation to cycloheximide (5 $\left.\mathrm{mg} \mathrm{l}^{-1}\right)$; Yamazaki et al., 1976, and unpublished results]. Their arrangements on their respective chromosomes are obscure at present since tetratype tetrads do not occur at meiosis in this yeast. To determine mating types, strains $11 \mathrm{~A}_{11} \mathrm{~S}_{1}$ (ATCC 26617; $a$ ) and $11 \mathrm{~A}_{11} \mathrm{~S}_{2}$ (ATCC 26618; $\alpha$ ) were used as standards as described previously (Yamazaki et al., 1976). The symbols used for the genetic markers follow the proposals made by the Genetic Nomenclature Committee for Yeast (Sherman \& Lawrence, 1974; Plischke et al., 1976); the numbers indicating different loci for a certain phenotype are designated independently from those in Saccharomyces cerevisiae.

Media and cultivation methods. The composition and method of preparation of malt extract (15 degrees Balling; $d_{4}^{17 \cdot 5}=1.0613$ ), synthetic nutrient, minimal, and sporulation media and the cultivation methods were as described previously (Yamazaki et al., 1976). To differentiate diploid and haploid cells in a singlespore culture, a dye-plate method was devised after several trials with trypan blue $\left(\mathrm{C}_{34} \mathrm{H}_{24} \mathrm{~N}_{6} \mathrm{O}_{14} \mathrm{~S}_{4} \mathrm{Na}_{4}\right.$, colour index no. 23850; Tokyo Kasei Co., Tokyo, Japan), eosin $\left(\mathrm{C}_{20} \mathrm{H}_{6} \mathrm{O}_{5} \mathrm{Br}_{4} \mathrm{Na}_{2}\right.$, colour index no. 45380; Kosoh Kagaku, Tokyo, Japan), magdala red $\left(\mathrm{C}_{30} \mathrm{H}_{21} \mathrm{~N}_{4} \mathrm{Cl}\right.$, colour index no. 50375; Tokyo Kasei Co. $)$ and phloxine $\mathrm{B}$ $\left(\mathrm{C}_{20} \mathrm{H}_{2} \mathrm{O}_{5} \mathrm{Br}_{4} \mathrm{Cl}_{4} \mathrm{Na}_{2}\right.$, colour index no. 45410 ; Tokyo Kasei Co. $)$ on a basal medium of modified Strömnaes' ASM medium (Strömnaes, 1968) containing (per litre) $1.0 \mathrm{~g}$ yeast extract (Difco), $1.0 \mathrm{~g}$ polypeptone (Daigo Eiyo), $20 \mathrm{~g}$ glucose, $1.5 \mathrm{~g} \mathrm{KH}_{2} \mathrm{PO}_{4}, 1.5 \mathrm{~g}\left(\mathrm{NH}_{4}\right)_{2} \mathrm{SO}_{4}, 1.0 \mathrm{~g} \mathrm{MgSO} \mathrm{MgH}_{4} \mathrm{O}$ and $12 \mathrm{~g}$ agar. [The amounts of yeast extract and polypeptone were both reduced to $1.0 \mathrm{~g}$ from $1.5 \mathrm{~g}$ in the original formula since this allowed clearer differentiation. Addition of Tween 80 (Nagai, 1963) gave a poor result.] The dyes were dissolved in distilled water at an appropriate concentration and sterilized at $100^{\circ} \mathrm{C}$ for $1 \mathrm{~h}$. Dye solution was added to the molten medium at $55^{\circ} \mathrm{C}$ to give the required concentration of dye. The medium was adjusted to $\mathrm{pH} 5.6$ with $1 \mathrm{M}-\mathrm{NaOH}$ solution before sterilization by autoclaving at $121^{\circ} \mathrm{C}$ for $15 \mathrm{~min}$.

Genetic techniques. Determination of mating types and tetrad dissection were performed according to the procedures described previously (Yamazaki et al., 1976). In the standard procedure for mating two haploid strains of opposite mating types in $S d$. ludwigii, the cells were cultivated separately in malt extract, washed with sterile distilled water and suspended to give approximately $10^{8}$ cells ml-1 in synthetic nutrient medium containing $1 \%(\mathrm{w} / \mathrm{v}) \mathrm{NaCl}$. Approximately equal amounts of the cell suspensions of opposite mating types were mixed; heavy agglutination of cells occurred immediately. The mixed culture was left to stand at $30^{\circ} \mathrm{C}$ overnight to allow formation of zygotes; the cell aggregate was then washed with distilled water to disperse the cells (this occurred readily in the absence of $\mathrm{Na}^{+}$, and zygotes were isolated with a micromanipulator. To determine the frequency of ascus formation, cells cultivated on malt extract agar at $30^{\circ} \mathrm{C}$ for $3 \mathrm{~d}$ were smeared on sporulation medium and incubated at $25^{\circ} \mathrm{C}$ for $7 \mathrm{~d}$. Then some of the cells were transferred on the tip of a platinum wire into 1 to $3 \mathrm{ml}$ water to give a suspension of suitable density for counting. The frequency of asci was scored by counting at least 2000 cells of each sample under a microscope.

Determination of cell volume, dry weight and DNA content. The volume of cells grown in malt extract at $30^{\circ} \mathrm{C}$ for $3 \mathrm{~d}$ was calculated using a Coulter Channelyzer (model ZBI, Coulter Electronics). The cell volume at the highest peak of cellular distribution was scored against human erythrocytes as standard $\left(80 \mu \mathrm{m}^{3}\right.$ per cell). In general, the values obtained with the Coulter Channelyzer were approximately $1 \cdot 2$ times larger than the mean value calculated from direct measurement of the short and long axes of cells on a photomicrograph, assuming that cells are ellipsoidal. This discrepancy might be due to a biased distribution of cell volumes. Cells used for determination of dry weight and DNA content were cultivated by shaking for $3 \mathrm{~d}$ at $30^{\circ} \mathrm{C}$ in $100 \mathrm{ml}$ synthetic nutrient medium in a $500 \mathrm{ml}$ Sakaguchi flask. They were harvested, washed twice and suspended in distilled water at approximately $7 \times 10^{8} \mathrm{ml}^{-1}$. Cells sedimented by centrifugation from $1 \mathrm{ml}$ suspension were dried at $105^{\circ} \mathrm{C}$ to constant weight for the determination of dry weight. DNA was extracted by the method of Schneider (1945) from $10 \mathrm{ml}$ cell suspension without elimination of acid-soluble and lipoid materials. DNA contents were determined by reading absorbance at $600 \mathrm{~nm}$ using a diphenylamine reagent according to the method of Burton (1956) with salmon sperm DNA (Wako Pure Chemicals Co., Osaka, Japan) as standard. A portion of the same cell suspension was diluted appropriately and the number of cells was counted in a Thoma haemocytometer. 


\section{RESULTS}

\section{Identification of diploid colonies}

In previous communications (Ohara et al., 1968; Yamazaki et al., 1970), we reported that diploid clones showing mating potency are thought to occur in a single-spore culture. For example, a culture of the haploid strain RY45-32C contained a few giant cells (Fig. 1, arrowed) and a preponderance of uniformly small cells (Figs 1,2a). To identify the ploidy of cells, we tested several dyes (trypan blue, eosin, magdala red and phloxine B) on agar plates of modified Strömnaes' ASM medium. Giant and small cells of strains RY45-32B and RY45-32C were isolated by micromanipulation and spread on dye plates containing various combinations and concentrations of the dyes. The most effective combination found for differentiation of these cells was $15 \mu \mathrm{g}$ trypan blue and $10 \mu \mathrm{g} \cdot \mathrm{phloxine} \mathrm{B} \mathrm{ml} \mathrm{m}^{-1}$ in the medium. On this dye medium colonies of the giant cells stained dark violet, while those of the small cells coloured pale violet. To confirm the effectiveness of the method, we spread cells of strains RY45-32B and RY45-32C on the dye plates, incubated the plates at $30^{\circ} \mathrm{C}$ for $7 \mathrm{~d}$ and isolated colonies coloured dark violet or pale violet. All of the dark-violet clones tested (27 from strain RY45-32B and 28 from RY45-32C) showed the same mating potency as their original strains. All the 55 dark-violet clones showed low but significant sporulation potency, while none of 30 pale-coloured isolates of each strain formed spores (Table 1). Cells of the dark-violet clones (RY45-32CG is illustrated in Fig. 2b) were significantly larger than those of the pale-violet ones (RY45-32C; Fig. 2a) on microscopic examination. We also determined the distribution of cell volumes with the Coulter Channelyzer for 10 randomly selected clones from each class of isolate. Cell volumes of dark-violet clones were $226 \pm 4.5 \mu \mathrm{m}^{3}$ (derivatives of RY45-32B) or $211 \pm 6.1 \mu \mathrm{m}^{3}$ (derivatives of RY45-32C) at the highest peak of distribution of cell volumes (Table 1). These values are significantly larger than those for the pale-violet clones $\left(143 \pm 6.9 \mu \mathrm{m}^{3}\right.$ for derivatives of RY45-32B and $144 \pm 6 \cdot 1 \mu \mathrm{m}^{3}$ for derivatives of RY45-32C). Two clones showing average cell size were selected from each class of isolate and their cell dry weight and DNA content were determined. The representative dark-violet clones, RY45-32BG and RY45-32CG (G denotes giant) isolated from strains RY45-32B ( $\alpha$ arg1 met 1) and RY45-32C (a argl met1), respectively, had significantly higher DNA content and almost twice the cell dry weight of the corresponding pale-violet clones. They were sporulated and four-spored asci were dissected. All the tetrad clones in 11 asci from RY45-32BG and 17 asci from RY45-32CG were auxotrophic for arginine and methionine, and the segregants from the former isolate showed $\alpha$ mating type, while those from the latter showed $a$. We concluded that the dark-violet clones from these haploid strains are diploids homozygous for all the genetic markers including mating type, and that the dye plate is effective for discrimination of colonies of homozygous diploid cells from those of haploid cells.

The frequency of diploid cells in a single-spore culture was determined by spreading cells on the dye plate. Single-spore cultures of RY45-S1 ( a arg1 met1) and RY45-S2 ( $\alpha$ arg1 met 1 ) from the same ascus were prepared with newly isolated spores from strain RY45. The colony developed from a single spore placed on a piece of cellophane film on a thin agar block and incubated at $30^{\circ} \mathrm{C}$ for $1 \mathrm{~d}$ was inoculated into $7 \mathrm{ml}$ malt extract, by transferring the whole piece of cellophane film, and incubated at $30^{\circ} \mathrm{C}$. Samples $(1 \mathrm{ml})$ of each culture were taken after $3 \mathrm{~d}$, spread on dye plates after appropriate dilution with sterile water and incubated at $30^{\circ} \mathrm{C}$ for $7 \mathrm{~d}$. Dark-violet colonies occurred with a frequency of $5.7 \times 10^{-3}$ for RY45-S1 and $1.8 \times 10^{-3}$ for RY45-S2.

\section{Mechanism of diploidization}

Winge \& Roberts (1958) suggested two alternative mechanisms for the appearance of homozygous diploid cells in a single-cell culture of yeasts: (i) fusion between two cells of 


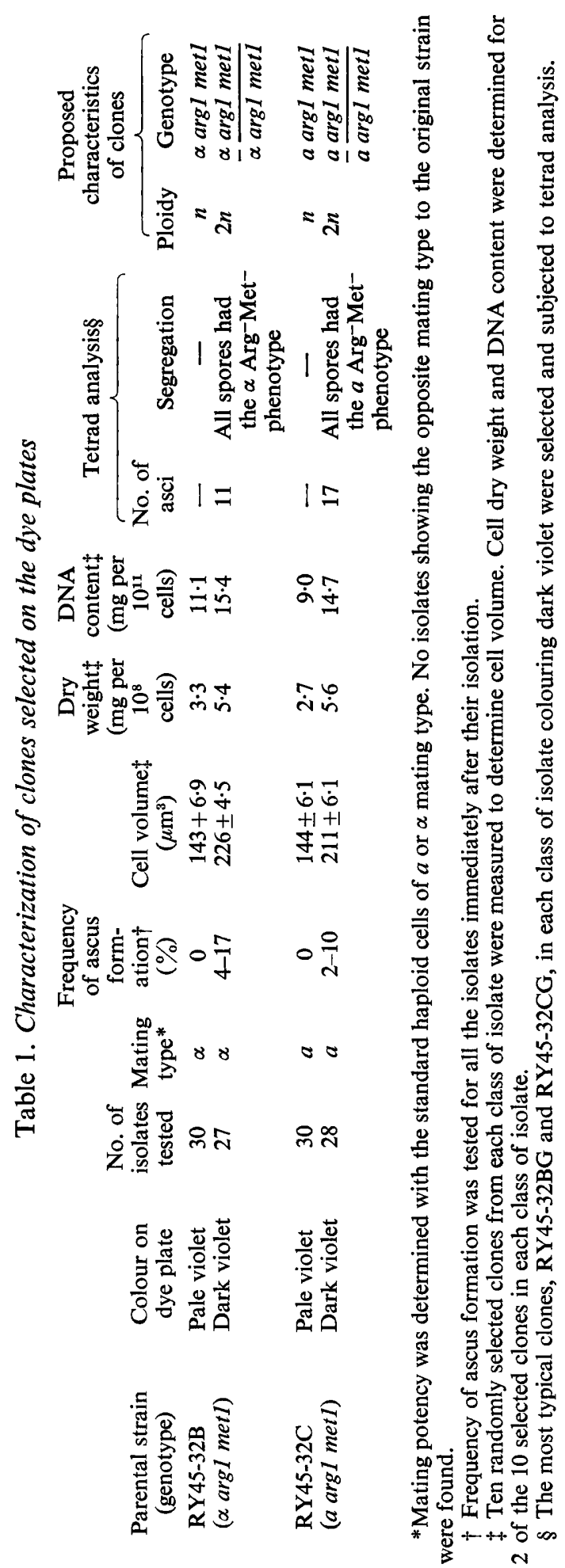


the same mating type, and (ii) fusion of two daughter nuclei in a budding cell (direct diploidization). However, these possibilities have been negated for the normal process of diploidization in $S$. cerevisiae and related species, even in homothallic strains. In heterothallic strains of Saccharomyces yeasts, diploidization almost always occurs by the fusion of two cells of opposite mating type (Lindegren \& Lindegren, 1943; Gunge \& Nakatomi, 1972). Rarely, illegitimate fusion occurs between cells of the same mating type (Lindegren \& Lindegren, 1943), in most cases between $\alpha$ and $\alpha$ cells (Roman, 1962). In homothallic strains, diploidization takes place in a single-spore culture by fusion of two cells. However, it has been proved that zygote formation is caused by mating-type conversion, which occurs in some fraction of the cells through the action of homothallic genes, and that fusion occurs between converted and unconverted cells (Oshima \& Takano, 1971; Harashima et al., 1974).

To test whether diploidization occurs by cell fusion between two haploid cells of identical mating type in $S d$. ludwigii, cells of the test strains were subjected to mating in all the possible combinations of complementary nutritional requirements according to the standard procedure. The mixed cultures were left at $30^{\circ} \mathrm{C}$ overnight and the cells were spread on minimal plates after washing and appropriate dilution. These plates were incubated at $30^{\circ} \mathrm{C}$ for $5 \mathrm{~d}$. No prototrophic colonies appeared from $3 \times 10^{7}$ cells tested in each of the RY45-32C $(a) \times$ Y 27-4A $(a)$ and RY45-32B $(\alpha) \times$ Y27-4B $(\alpha)$ combinations, whereas numerous prototrophic colonies were observed in similar experiments with the RY45-32C $(a) \times \mathrm{Y} 27-4 \mathrm{~B}(\alpha)$, RY45-32B $(\alpha) \times$ Y27-4A $(a)$ and Y27-4A $(a) \times$ Y27-4B $(\alpha)$ combinations. In general, cells in mixed cultures of like mating type did not show aggregation, unlike those in combinations of complementary mating types. To facilitate cell contact, cells in the mixed cultures of identical mating type were sedimented by centrifugation at $3000 \mathrm{rev}$. $\mathrm{min}^{-1}$ for $5 \mathrm{~min}$ and left at $30^{\circ} \mathrm{C}$ for $5 \mathrm{~d}$. They were then spread on minimal plates after appropriate dilution and the plates were incubated at $30^{\circ} \mathrm{C}$ for $5 \mathrm{~d}$. We observed only 2 prototrophic colonies on minimal plates from $3.3 \times 10^{8}$ cells in the RY45-32C $\times$ Y27-4A cross and 11 prototrophic colonies from $5 \cdot 4 \times 10^{8}$ cells in the $\mathrm{RY} 45-32 \mathrm{~B} \times \mathrm{Y} 27-4 \mathrm{~B}$ cross. The prototroph frequencies are significantly lower than the frequency of homozygous diploid colonies colouring dark violet on the dye plate (approximately $5 \times 10^{-3}$ ). These observations clearly indicate that the homozygous diploid clones did not arise through cell fusion and strongly suggest that nuclear fusion occurs in budding cells. This argument is supported by Hjort's (1954) observation on the formation of an open bud at spore germination, which suggests intracellular self-diploidization. Saccharomycodes ludwigii has lemon-shaped cells and reproduction occurs by bipolar budding on a broad base, followed by fission (Streiblová \& Beran, 1963). We frequently observed two connected cells forming a large cell (Fig. 1) which might be similar to the large cells observed by Hjort. Some of them were isolated by micromanipulation. The cell size of these isolates suggested they were diploids. For one isolate from strain RY45-32C, we determined the cell volume $\left(223 \mu \mathrm{m}^{3}\right)$, dry weight $(5 \cdot 3 \mathrm{mg}$ per $10^{8}$ cells), DNA content $\left(14.4 \mathrm{mg}\right.$ per $10^{11}$ cells), sporulation (frequency of ascus formation, $2 \%$ ) and homozygosity of the genetic markers (a arg1 metl/a arg1 met1) in nine fully recovered tetrads; all the data clearly indicated that the isolate was a homozygous diploid.

\section{Construction of polyploid cells}

Since the dark-violet clones are diploids homozygous for a mating-type allele and have mating potency, it was easy to construct triploid and tetraploid strains. For example, we obtained triploid and tetraploid strains using two dark-violet clones, RY45-32CG (Fig. 2b) and Y27-4BG, and their respective original haploid clones, RY45-32C ( $a$ arg1 met 1; Fig. $2 a$ ) and Y27-4B ( $\alpha$ his2). A heterozygous diploid clone, Y77 (Fig. $2 c$ ), was obtained by the RY45-32C $(a) \times$ Y27-4B $(\alpha)$ cross. Two triploid clones, Y78 (Fig. 2d) and Y79, were prepared by the RY45-32CG $(a / a) \times$ Y27-4B $(\alpha)$ and RY45-32C $(a) \times$ Y27-4BG $(\alpha / \alpha)$ 


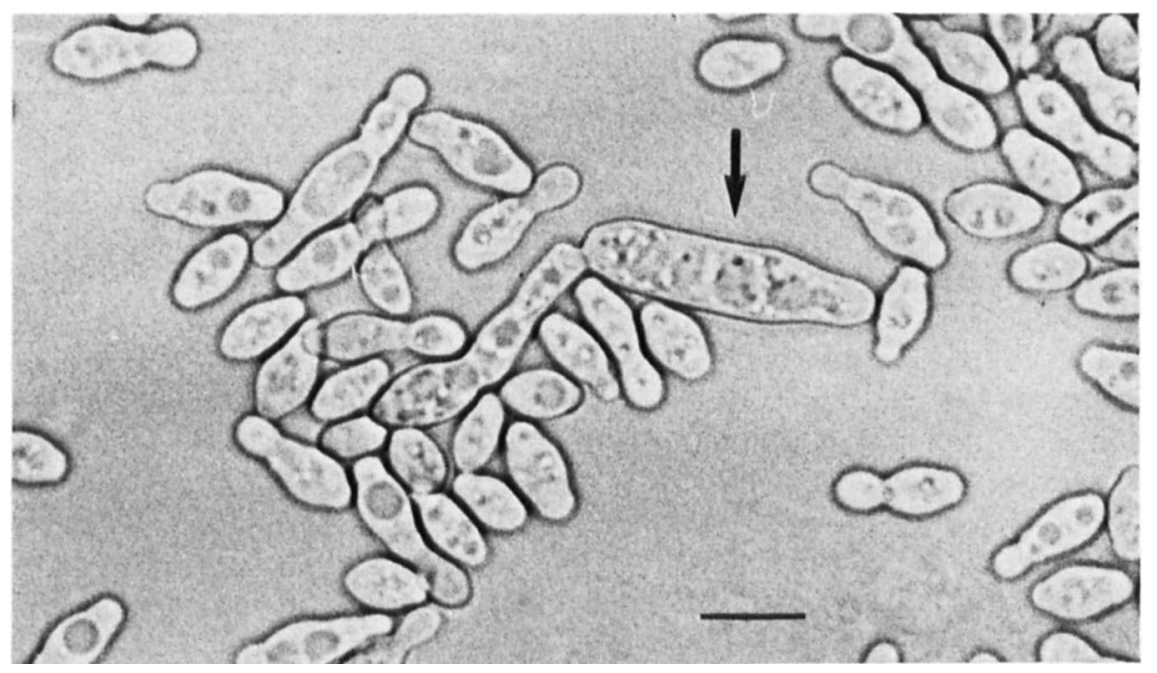

Fig. 1. Photomicrograph of a supposed direct-diploidizing cell (arrowed) in a culture of strain RY45-32C. The preparation was mounted in water and examined using bright field illumination. Bar marker represents $10 \mu \mathrm{m}$.

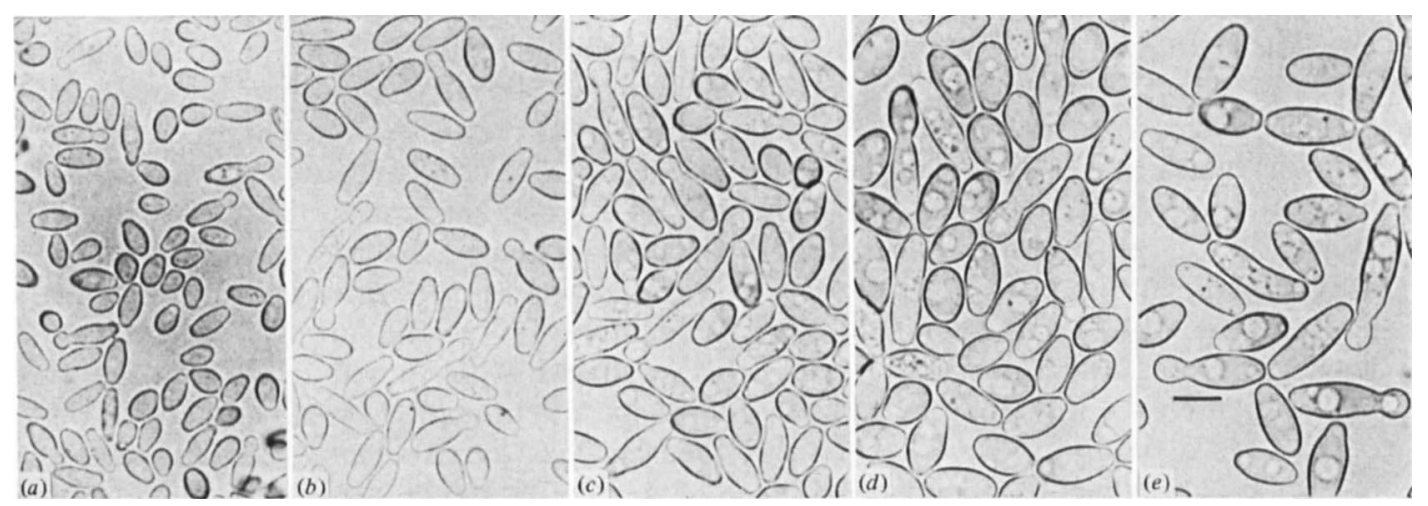

Fig. 2. Photomicrographs of cells with different ploidies: (a) haploid strain RY45-32C; (b) $a / a$ homozygous diploid strain RY45-32CG; $(c) a / \alpha$ heterozygous diploid strain Y77 prepared by the RY45-32C $(a) \times$ Y27-4B $(\alpha)$ cross; $(d) a / a / \alpha$ heterozygous triploid strain Y78 prepared by the RY4532CG $(a / a) \times$ Y27-4B $(\alpha)$ cross; $(e) a / a / \alpha / \alpha$ heterozygous tetraploid strain Y80 prepared by the RY45-32CG $(a / a) \times$ Y27-4BG $(\alpha / \alpha)$ cross. Cells were inoculated into malt extract and the cultures were left to stand at $30^{\circ} \mathrm{C}$ for $3 \mathrm{~d}$. All photomicrographs were taken with the same magnification using bright field illumination; the bar marker (in $e$ ) represents $10 \mu \mathrm{m}$.

crosses, respectively, and the RY45-32CG $(a / a) \times$ Y27-4BG $(\alpha / \alpha)$ cross gave rise to a tetraploid clone, Y80 (Fig. $2 e$ ). Their sporulation abilities, cell volumes, dry weights and DNA contents are listed in Table 2, along with comparable data for the diploid strain O-81, which was isolated from the natural habitat (Ohara et al., 1964) and is the progenitor of all the strains used in the present study. All strains showed a significant sporulation potency. From these and other similar data, the approximate cell weight in most cases was found to be given by the equation $W=2 \cdot 6 n+0 \cdot 4$, where $W$ is the cell weight in mg per $10^{8}$ cells and $n$ is the ploidy of the cells. Similar relationships were also observed between ploidy and (i) cell volume (105 to $144 \mu \mathrm{m}^{3}$ per cell per genome) and (ii) DNA content (6.1 to $9.0 \mathrm{mg}$ per $10^{11}$ cells per genome), although haploid cells gave higher values than predicted by these relationships. 
Table 2. Ascus formation, cell volume, dry weight and DNA content of the diploid strains and the suspected triploid or tetraploid strains

\begin{tabular}{|c|c|c|c|c|c|c|}
\hline Strain & $\begin{array}{l}\text { Combination } \\
\text { (genotype) }\end{array}$ & Ploidy & $\begin{array}{l}\text { Frequency of } \\
\text { ascus } \\
\text { formation } \\
\quad(\%)\end{array}$ & $\begin{array}{c}\text { Cell } \\
\text { volume } \\
\left(\mu \mathrm{m}^{3}\right)\end{array}$ & $\begin{array}{c}\text { Dry } \\
\text { weight } \\
\text { (mg per } \\
10^{8} \text { cells) }\end{array}$ & $\begin{array}{c}\text { DNA } \\
\text { content } \\
\text { (mg per } \\
10^{11} \text { cells) }\end{array}$ \\
\hline $\begin{array}{l}\text { O-81 } \\
\text { Y77 }\end{array}$ & $\begin{array}{l}\text { Original diploid strain } \\
\text { RY45-32C ( } a \text { arg1 met } 1) \\
\times \text { Y27-4B }(\alpha \text { his } 2)\end{array}$ & $\begin{array}{l}2 n \\
2 n\end{array}$ & $\begin{array}{l}58 \\
42\end{array}$ & $\begin{array}{l}241 \\
233\end{array}$ & $\begin{array}{l}5 \cdot 8 \\
5 \cdot 3\end{array}$ & $\begin{array}{l}16 \cdot 1 \\
14 \cdot 5\end{array}$ \\
\hline Y78 & $\begin{array}{l}\mathrm{RY} 45-32 \mathrm{CG}\left[\frac{a}{a} \frac{\arg 1 \text { met1 }}{\operatorname{argl} m e t 1}\right] \\
\times \mathrm{Y} 27-4 \mathrm{~B}(\alpha \text { his })\end{array}$ & $3 n$ & 34 & 330 & $8 \cdot 3$ & 20.5 \\
\hline Y79 & $\begin{array}{l}\mathrm{RY} 45-32 \mathrm{C}(\text { (a arg1 metl) } \\
\quad \times \mathrm{Y} 27-4 \mathrm{BG}\left[\frac{\alpha \text { his } 2}{\alpha \text { his } 2}\right]\end{array}$ & $3 n$ & 46 & 318 & $8 \cdot 7$ & $18 \cdot 3$ \\
\hline Y80 & $\begin{array}{l}\mathrm{RY} 45-32 \mathrm{CG}\left[\frac{a}{a} \frac{\text { arg1 met1 }}{\operatorname{arg1} \text { met1 }}\right] \\
\times \mathrm{Y} 27-4 \mathrm{BG}\left[\frac{\alpha \text { his } 2}{\alpha \text { his } 2}\right]\end{array}$ & $4 n$ & 53 & 437 & $11 \cdot 0$ & $25 \cdot 2$ \\
\hline
\end{tabular}

Table 3. Tetrad segregation in asci from the diploid and polyploid strains

\begin{tabular}{|c|c|c|c|c|c|c|c|c|c|}
\hline \multirow[b]{2}{*}{ Strain } & \multirow[b]{2}{*}{ Ploidy } & \multicolumn{2}{|c|}{ No. of asci } & \multicolumn{2}{|c|}{$\begin{array}{l}\text { Segregation for } \\
\text { mating type }\end{array}$} & \multicolumn{4}{|c|}{$\begin{array}{c}\text { No. of asci showing specified } \\
\text { segregation } \ddagger\end{array}$} \\
\hline & & Dissectec & $\begin{array}{c}\text { Re- } \\
\text { covered* }\end{array}$ & non $\uparrow: a: \alpha$ & $\begin{array}{l}\text { No. of } \\
\text { asci }\end{array}$ & $+:-$ & Arg & Met & His \\
\hline Y77 & $2 n$ & 10 & 10 & $\begin{array}{l}4: 0: 0 \\
2: 2: 0 \\
0: 2: 2\end{array}$ & $\begin{array}{r}0 \\
0 \\
10\end{array}$ & $\begin{array}{l}4: 0 \\
3: 1 \\
2: 2\end{array}$ & $\begin{array}{c}0 \\
0 \\
10 \S\end{array}$ & $\begin{array}{c}0 \\
0 \\
10 \S\end{array}$ & $\begin{array}{r}0 \\
0 \\
10\end{array}$ \\
\hline Y78 & $3 n$ & 72 & 0 & & - & & - & - & - \\
\hline Y79 & $3 n$ & 36 & 2 & $\begin{array}{l}4: 0: 0 \\
2: 0: 2 \\
0: 2: 2\end{array}$ & $\begin{array}{l}0 \\
2 \\
0\end{array}$ & $\begin{array}{l}4: 0 \\
3: 1 \\
2: 2\end{array}$ & $\begin{array}{l}2 \\
0 \\
0\end{array}$ & $\begin{array}{l}2 \\
0 \\
0\end{array}$ & $\begin{array}{l}0 \\
0 \\
2\end{array}$ \\
\hline Y80 & $4 n$ & 100 & 50 & $\begin{array}{l}4: 0: 0 \\
2: 2: 0 \\
0: 2: 2\end{array}$ & $\begin{array}{r}27 \\
21 \\
21\end{array}$ & $\begin{array}{l}4: 0 \\
3: 1 \\
2: 2\end{array}$ & $\begin{array}{c}41 \\
0 \\
9 \S\end{array}$ & $\begin{array}{c}41 \\
0 \\
98\end{array}$ & $\begin{array}{r}29 \\
0 \\
21\end{array}$ \\
\hline
\end{tabular}

* Asci in which all four tetrad clones were recovered are listed. Segregation patterns in the incomplete tetrads (not listed) were consistent with the observations for full tetrads.

$\dagger$ Non-mater, unable to mate with the $a$ and $\alpha$ testers.

$\ddagger$ For example, of the 50 asci from $\mathrm{Y}^{80}, 41$ showed $4 \mathrm{Arg}^{+}: 0 \mathrm{Arg}^{-}$and $4 \mathrm{Met}^{+}: 0 \mathrm{Met}^{-}$segregations, whereas 9 showed $2 \mathrm{Arg}^{+}: 2 \mathrm{Arg}^{-}$and $2 \mathrm{Met}^{+}: 2 \mathrm{Met}^{-}$segregations.

$\S$ The arginine (Arg) and methionine (Met) traits segregated together and showed a $2 \mathrm{Arg}^{+} \mathrm{Met}^{+}: 2 \mathrm{Arg}^{-} \mathrm{Met}^{-}$ segregation in these asci.

These polyploid strains were also subjected to tetrad analysis. In the diploid strain Y77, all the markers including mating type showed 2:2 segregations as expected (Table 3 ). In the supposed tetraploid strain Y80, the argl metl and his 2 markers segregated as 4+:0or $2+: 2-$ in all 50 asci tested, and mating types showed 4 non:0a:0 $\alpha$ or $2 a: 2 \alpha$ segregations (where non indicates non-mater segregants, i.e. those that failed to mate with either of the standard haploid strains of $a$ and $\alpha$ mating type) in 48 of the 50 asci tested, the other two showing a 2 non: $2 a: 0 \alpha$ segregation. This observation indicates that crossing-over did not occur between these markers and their respective centromeres at meiosis of the tetraploid cells (Roman et al., 1955) and accords with the previous observation that recombination between two genes on the same linkage group did not occur in the meiotic division of $a / \alpha$ diploids (Yamazaki et al., 1976). The two exceptional asci from strain Y80 showing a 2non:2a:0 $\alpha$ segregation for mating type might have arisen through non-disjunction of 
chromosome I at the first meiotic division. We dissected 36 asci and recovered only two full tetrads from the supposed triploid strain Y79. The segregation pattern in these two asci accorded with the expectation that strain $Y 79$ is triploid with genotype $\alpha / \alpha / a,+/+/ \arg 1$, $+/+/$ met 1 , his $2 /$ his $2 /+$ and that tetratype asci would not occur for any gene pair at meiosis. No full tetrads were recovered in the other triploid, Y78, from 72 asci dissected.

Some of the segregants from the supposed tetraploid strain Y80 sporulated and the resultant asci were dissected and analysed (Table 4). Those segregants showing sporulation were diploid, some having the $a / \alpha$ and others $a / a$ or $\alpha / \alpha$ genotype at the mating-type locus. When the asci produced by the segregants showed $2 a: 2 \alpha$ segregation of mating-type alleles and $2+: 2-$ segregation of auxotrophic markers, the segregation patterns (Table 4) supported the previous finding (Yamazaki et al., 1976) that recombination did not occur for the gene-pairs arg1-met1 and his2- $\alpha$, for which linkage was suggested.

Four $\alpha$ mating-type clones in the segregants from the supposed triploid strain Y79 (Table 3) could not sporulate. Their cell volume (86 to $107 \mu \mathrm{m}^{3}$ per cell), dry weight (3.3 to $3.8 \mathrm{mg}$ per $10^{8}$ cells) and DNA content $\left(6.2\right.$ to $10.7 \mathrm{mg}$ per $10^{11}$ cells) clearly indicated that they were haploids. Four non-maters from the same family were identified as $a / \alpha$ diploids, since they could sporulate well and showed $2 a: 2 \alpha$ segregation in each ascus on tetrad analysis. Their cell volume (223 to $226 \mu \mathrm{m}^{3}$ per cell), dry weight $\left(5 \cdot 1\right.$ to $5 \cdot 3 \mathrm{mg}$ per $10^{8}$ cells) and DNA content $\left(11.2\right.$ to $13.5 \mathrm{mg}$ per $10^{11}$ cells) also support this conclusion. As with the previous diploids, no tetratype ascus was observed in the segregation of genetic markers on sporulation of these diploids.

\section{DISCUSSION}

In the natural habitat, diploidization can occur in $S d$. ludwigii by fusion of two coherent spores at each end of a four-spored ascus as the spores germinate. Other legitimate diploidizations, by cell-to-cell or spore-to-spore fusion between opposite mating types, can also be performed effectively, as heterothallism has been observed in this yeast (Yamazaki et al., 1969). However, in this study, we detected, using the dye-plate method, the occurrence of diploid cells in a haploid culture at a frequency of approximately $5 \times 10^{-3}$. The diploid cells were homozygous for all the genetic markers in the haploid strains, including mating type. The dye-plate method gave reliable detection of homozygous diploid colonies among haploid colonies. However, we tested the same method for the identification of colonies of $a / \alpha$ diploid, $a / a / \alpha$ (or $a / \alpha / \alpha$ ) triploid, and $a / a / \alpha / \alpha$ tetraploid cells in a major population of haploid cells and found it ineffective, since diploid, triploid and tetraploid colonies coloured the same pale violet as haploid colonies (data not shown). Similar dye-plate methods have been described by others for identifying various traits in yeast cells. Nagai (1963) recommended magdala red or a mixture of eosin and trypan blue for detection of respiratorydeficient mutants over a broad range of Saccharomyces species. Horn \& Wilkie (1966) found phloxine B suitable for the detection of auxotrophic mutants and Middelhoven et al. (1976) found it suitable for detecting mutants in $S$. cerevisiae unable to degrade certain nitrogen compounds. The descriptions of the dyes given by Horn \& Wilkie (1966) and Middelhoven et al. (1976) are unclear and there is possible confusion between phloxine B and magdala red; however, from the colour code index numbers cited they were most likely phloxine B (Lillie et al., 1969). The dye used by Nagai (1963) was definitely magdala red (S. Nagai, personal communication). Though the physiological rationale behind the staining of the vital cells is not clear, the wide applicability of similar dye-plate methods for traits in yeast indicates that the method is reliable for detecting relative variety classes in a mother population.

Since the frequency of prototrophic colonies in the mass mating between cells of two strains of identical mating type and complementary for several auxotrophic markers was very low (approximately $1 \times 10^{-8}$ ) in comparison with that of the dark-violet colonies among 


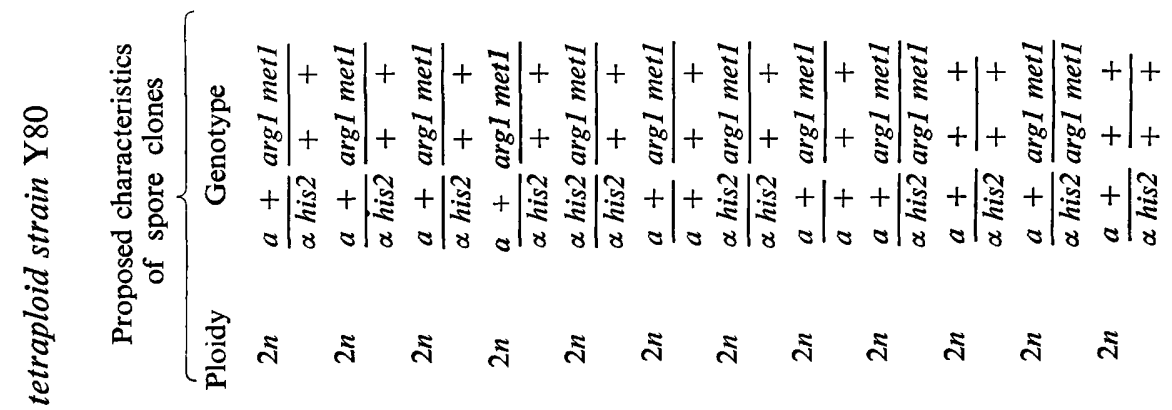

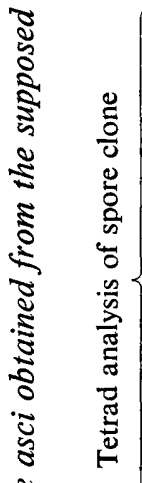

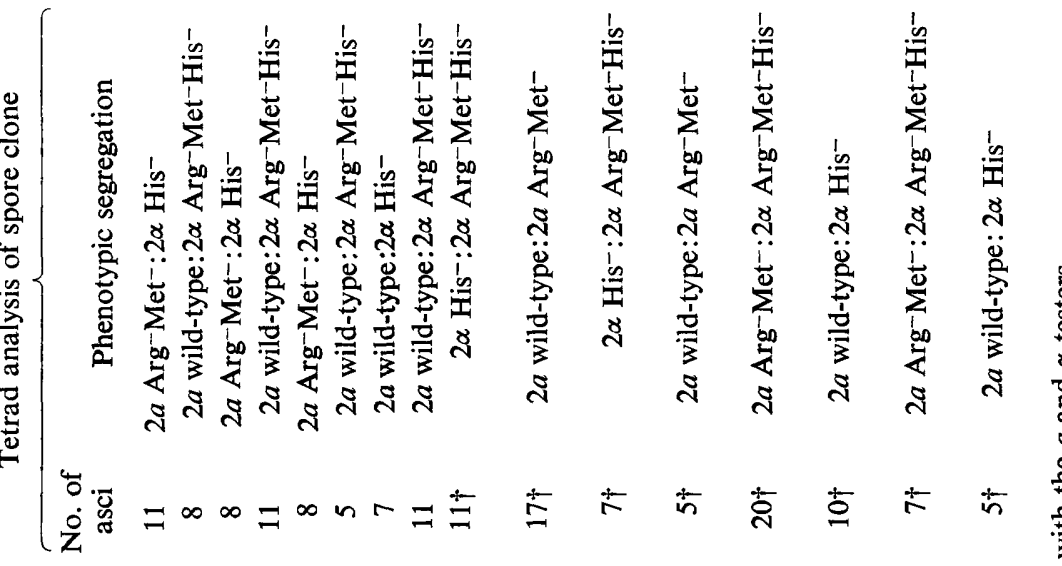

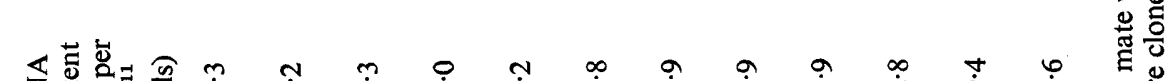

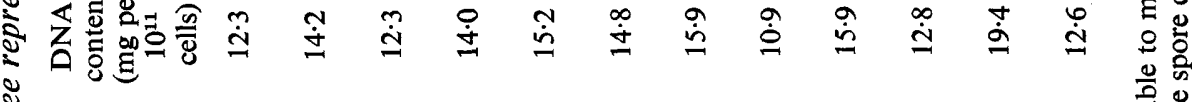
$\stackrel{2}{\Sigma}$

志

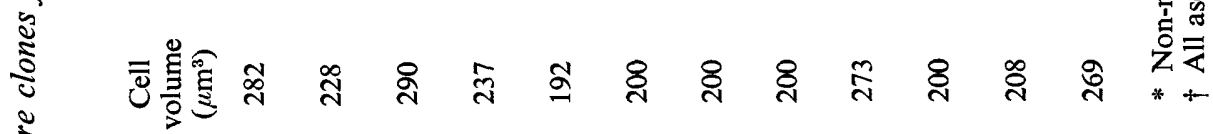

ఏั

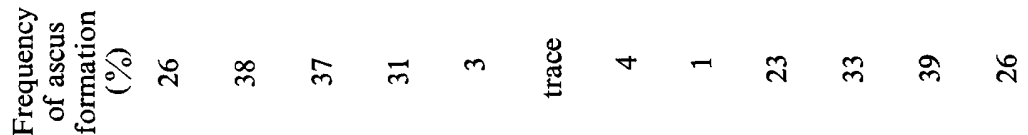
$\frac{5}{5} \quad$ 离



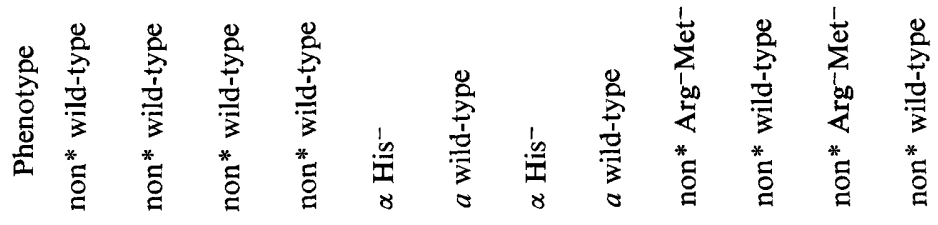

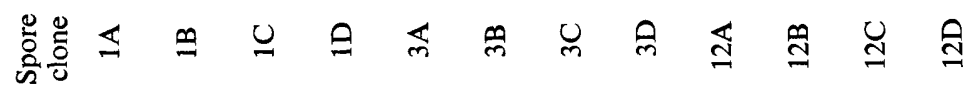


the pale-violet haploid colonies (approximately $5 \times 10^{-3}$ ), these two phenomena are independent. Hence the homozygous diploid cells probably arise not through cell fusion but through endomitosis (no nuclear division after chromosome duplication) or through direct diploidization (fusion of mother and daughter nuclei before cytokinesis). Endomitosis is thought to occur in Schizosaccharomyces pombe (U. Leupold, cited in Gutz et al., 1974) and direct diploidization was first suggested in a Danish baking yeast by Winge \& Laustsen (1937). However, we have not observed these processes in our genetic studies on several species of Saccharomyces yeasts. In the present study, we observed that the large (supposedly diploid) cells in a haploid culture were frequently connected at one end by an elongated cell. The attached elongated cell might be a pair of cells, possibly mother and daughter cells of the haploid, as they were small and connected through a broad base without a transverse wall (Fig. 1). These observations strongly suggest that the homozygous diploid cells originate by direct diploidization, and that nuclear fusion might have occurred in one of the attached haploid cells.

In $S$. cerevisiae and related species, diploidization generally occurs by fusion of two haploid cells, or spores, or between a cell and spore having complementary mating types, $a$ and $\alpha$, even in homothallic strains (Oshima \& Takano, 1971). Cell fusion between two haploid cells of identical mating type also occurs in low frequency. In general, the diploid cells produced by the fusion of $a$ and $\alpha$ cells are heterozygous for mating type and able to sporulate, while those homozygous for mating type, $a / a$ and $\alpha / \alpha$, are incapable of sporulation. However, some exceptional diploids homozygous for mating type have been reported to sporulate, and are known to be due to either dominant (Hopper \& Hall, 1975) or recessive (Gerlach, 1974; Kassir \& Simchen, 1976) modifier mutations.

In contrast to $S$. cerevisiae and its related species, most (if not all) of the diploid cells homozygous for mating type in $S d$. ludwigii could sporulate, though the frequency of ascus formation was low (approximately $5 \%$ ) in comparison with that of the diploid cells heterozygous for mating type. These observations indicate that wild-type $a / a$ and $\alpha / \alpha$ diploids in $S d$. ludwigii are able to sporulate and suggest there is a different mechanism from that in $S$. cerevisiae for the control of sporulation by the mating-type locus. The viability of spores from an ascus in the homozygous diploid was high and spores having exclusively one mating type, $a$ or $\alpha$, depending on the original haploid strain, were produced. Using diploid cells homozygous for mating type, it was easy to construct triploid and tetraploid cells. These observations strongly suggest the presence of polyploid cells of $S d$. ludwigii in the natural habitat and in cell populations of stock cultures.

The fact that no recombinant class was observed between genetic markers belonging to the same linkage group in the progeny throughout the present study strongly suggests the absence of crossing-over at meiosis in the polyploid cells, as previously found in diploid cells heterozygous for mating type (Yamazaki et al., 1976). However, mitotic recombination occurs in this yeast at a frequency which is almost the same or higher than that in S. cerevisiae (in general, less than $1 \times 10^{-5}$; Sherman \& Lawrence,1974). For example, whole or sectored pink colonies due to the ade1/adel configuration appeared spontaneously at a frequency of $2 \times 10^{-4}$ from ade1/ADE1 + diploid cells during vegetative growth (unpublished results). Chromosome mapping based on mitotic recombination is under investigation.

We wish to thank Professor Yuwao Ohara for his advice and encouragement throughout this work and Dr Susumu Nagai for his helpful discussions. We are also indebted to Dr Shiro Senoh, director of the Central Research Institute of Suntory Ltd, for access to the Coulter Channelyzer. This study was supported by grant no. 248053 to Y. Oshima from the Scientific Research Fund of the Ministry of Education, Japan. 


\section{REFERENCES}

Burton, K. (1956). A study of the conditions and mechanism of the diphenylamine reaction for the colorimetric estimation of deoxyribonucleic acid. Biochemical Journal 62, 315-323.

Gerlach, W. L. (1974). Sporulation in mating type homozygotes of Saccharomyces cerevisiae. Heredity 32, 241-249.

Gunge, N. \& Nakatomi, Y. (1972). Genetic mechanisms of rare matings of the yeast Saccharomyces cerevisiae heterozygous for mating type. Genetics 70, 41-58.

Gutz, H., Heslot, H., Leupold, U. \& Loprieno, N. (1974). Schizosaccharomyces pombe. In Handbook of Genetics, vol. 1, Bacteria, Bacteriophages and Fungi, pp. 395-446. Edited by R. C. King. New York: Plenum Press.

Harashima, S., Nogi, Y. \& Oshima, Y. (1974). The genetic system controlling homothallism in Saccharomyces yeasts. Genetics 77, 639-650.

HJoRT, A. (1954). Some studies on the genus Saccharomycodes Hansen. Comptes rendus des travaux du Laboratoire Carlsberg, Série Physiologique 25, 259-284.

Hopper, A. K. \& HALL, B. D. (1975). Mating type and sporulation in yeast. I. Mutations which alter mating-type control over sporulation. Genetics $\mathbf{8 0}$, 41-59.

Horn, P. \& Wilkie, D. (1966). Use of Magdala red for the detection of auxotrophic mutants of Saccharomyces cerevisiae. Journal of Bacteriology 91, 1388.

Kassir, Y. \& Simchen, G. (1976). Regulation of mating and meiosis in yeast by the mating-type region. Genetics 82, 187-206.

Lillie, R. D., Stotz, E. H., Emmel, V. M., Darrow, M. A. \& GlenNer, G. G. (1969). H.J. Conn's Biological Stains, $A$ Handbook on the Nature and Uses of the Dyes Employed in the Biological Laboratory, 8th edn. Baltimore: Williams \& Wilkins.

Lindegren, C. C. \& Lindegren, G. (1943). A new method for hybridizing yeast. Proceedings of the National Academy of Sciences of the United States of America 29, 306-308.

Middelhoven, W. J., Broekhuizen, B. \& VAN EIJK, J. (1976). Detection, with the dye phloxine B, of yeast mutants unable to utilize nitrogenous substances as the sole nitrogen source. Journal of Bacteriology 128, 851-852.

NagaI, S. (1963). Diagnostic colour differentiation plates for hereditary respiration deficiency in yeast. Journal of Bacteriology 86, 299-302.

Ohara, Y., Nonomura, H. \& YAMAZAKI, T. (1964). Dynamic aspect of yeast-flora during vinous fermentation. IX. Preferential isolation of wild yeast (III). Bulletin of the Research Institute of Fermentation, Yamanashi University 11, 1-12.

OHARA, Y., Nonomura, H. \& YamaZaKI, T. (1968). Studies on the single-spore cultures of Saccharomycodes ludwigii Hansen. I. The homozygous sporulation and the heterothallic agglutination. Journal of Fermentation Technology 46, 347-355.

Oshima, Y. \& TAKANO, I. (1971). Mating types in Saccharomyces: their convertibility and homothallism. Genetics 67, 327-335.

Plischke, M. E., von Borstel, R. C., Mortimer, R K \& CoHN, W. E. (1976). Genetic markers and associated gene products in Saccharomyces cerevisiae. In Handbook of Biochemistry and Molecular Biology, 3rd edn, Nucleic Acids vol. II, pp. 767-832. Edited by C. D. Fasman. Cleveland, Ohio: Chemical Rubber Co.

Roman, H. (1962). Sources of variability in vegetative yeast cultures. In Recent Progress in Microbiology, VIII International Congress for Microbiology, Montreal, 1962, pp. 306-312. Edited by N.E. Gibbons. Montreal: University of Toronto Press.

Roman, H., Phillips, M. M. \& SANDs, S. M. (1955). Studies of polyploid Saccharomyces. I. Tetraploid segregation. Genetics 40, 546-561.

SCHNEIDER, W. C. (1945). Phosphorus compounds in animal tissues. 1. Extraction and estimation of desoxypentose nucleic acid and of pentose nucleic acid. Journal of Biological Chemistry 161, 293-303.

Sherman, F. \& LaWrence, C. W. (1974). Saccharomyces. In Handbook of Genetics, vol. 1, Bacteria, Bacteriophages, and Fungi, pp. 359-393. Edited by R. C. King. New York: Plenum Press.

Streiblová, E. \& Beran, K. (1963). Type of multiplication scars in yeasts, demonstrated by fluorescence microscopy. Folia microbiologica 8 , 221-227.

STRömNAES, Ö. (1968). Genetic changes in Saccharomyces cerevisiae grown on media containing DL-para-fluorophenylalanine. Hereditas 59, 197220.

Winge, Ö. \& LAustsen, O. (1937). On two types of spore germination, and on genetic segregation in Saccharomyces, demonstrated through singlespore cultures. Comptes rendus des travaux du Laboratoire Carlsberg, Série Physiologique 22, 99-117.

WINGE, Ö. \& LAUSTSEN, O. (1939). Saccharomycodes ludwigii Hansen, a balanced heterozygote. Comptes rendus des travaux du Laboratoire Carlsberg, Série Physiologique 22, 357-370.

Winge, Ö. \& Roberts, C. (1958). Life history and cytology of yeasts. In The Chemistry and Biology of Yeasts, pp. 93-122. Edited by A. H. Cook. New York: Academic Press.

Yamazaki, T., Nonomura, H. \& OHara, Y. (1969). Studies on the single-spore cultures of Saccharomycodes ludwigii Hansen. III. Tetrad analysis of hybrids obtained by a crossing between spores and between cells of opposite agglutination type. Journal of Fermentation Technology 47, 670-676.

Yamazaki, T., Nonomura, H. \& Ohara, Y. (1970). Studies on the single-spore cultures of Saccharomycodes ludwigii Hansen. IV. The cellular dry weights, DNA contents and the polyploid rates of the cultures. Journal of Fermentation Technology 48, 655-659.

Yamazaki, T., Nonomura, H. \& OHaRA, Y. (1971). Studies on the single-spore cultures of Saccharomycodes ludwigii Hansen. VI. Heterocaryosis between cells with the opposite agglutination types. Part II. Nuclear process at the formation of cells with parental agglutination types, and of triploid, tetraploid and dicaryotic cells. Journal of Fermentation Technology 49, 829-835.

Yamazaki, T., OHaRa, Y. \& Oshima, Y. (1976). Rare occurrence of the tetratype tetrads in Saccharomycodes ludwigii. Journal of Bacteriology 125, 461-466. 